\title{
Sekolah Rakyat di Enrekang, 1950-1959
}

\author{
Musdalifah Muchlis, Jumadi, Muh. Rasyid Ridha \\ Prodi Pendidikan Sejarah Fakultas Ilmu Sosial Universitas Negeri Makassar \\ ifha1007@gmail.com
}

\begin{abstract}
Abstrak
Penelitian ini bertujuan untuk mengetahui kondisi pendidikan di Enrekang sebelum tahun 1950, sistem pendidikan sekolah rakyat dan perkembangan sekolah rakyat di Enrekang tahun 1950-1959. Sistem dan perkembangan sekolah rakyat dalam penelitian ini berfokus pada kebijakan pemerintah, partisipasi masyarakat, guru sekolah rakyat, minat murid, kondisi dan peralatan sekolah. Jenis penelitian ini adalah penelitian Kualitatif, dengan menggunakan metode sejarah melalui tahapan: heuristik (pengumpulan sumber), kritik sumber, interpretasi, dan historiografi. Hasil penelitian menunjukkan bahwa sekolah rakyat sudah ada pada masa pemerintahan Belanda tahun 1905 sedangkan di Enrekang tahun 1926 namun nama Volkschool. Nama sekolah Rakyat dipakai setelah Indonesia merdeka. Kondisi Sekolah rakyat di Enrekang sebelum tahun 1950 masih dalam keadaan terbelakang namun setelah lima tahun merdeka keadaan sudah semakin membaik. Sistem pendidikan sekolah rakyat setelah kemerdekaan terutama dalam kurikulum yang awalnya hanya belajar membaca, menulis dan berhitung kini semakin bertambah.seperti contohnya belajar sejarah. Sekolah rakyat di Enrekang mengalami perkembangan di lihat dari semakin banyaknya sekolah yang berubah dari SR 3 atau 4 menjadi 6 tahun karena jumlah siswa bertambah. Perkembangan tersebut karena adanya peran aktif masyarakat dan pemerintah yang turut andil dalam kemajuan pendidikan.
\end{abstract}

\section{Kata Kunci: Sekolah rakyat dan Enrekang.}

\begin{abstract}
This study aims to determine the condition of education in Enrekang before 1950, the education system of public schools and the development of community schools in Enrekang in 1950-1959. The system and development of community schools in this study focused on government policy, community participation, community school teachers, student interests, school conditions and equipment. This type of research is a qualitative study, using the historical method through stages: heuristics (source collection), source criticism, interpretation, and historiography. The results showed that the people's school had existed during the Dutch administration in 1905 while in Enrekang in 1926 the name was Volkschool. The name People's school was used after Indonesian independence. The condition of people's schools in Enrekang before 1950 was still underdeveloped, but after five years of independence the situation had improved. The education system of the people's schools after independence, especially in the curriculum which initially only learned to read, write and count is now increasing. For example studying history. Public schools in Enrekang are experiencing growth in view of the increasing number of schools that change from SR 3 or 4 to 6 years as the number of students increases. This development was due to the active role of the community and the government that contributed to the progress of education.
\end{abstract}

Keywords: Community school and Enrekang

Vol. 6 No. 2, Agustus 2019, 88-98 | 88 


\section{A. Pendahuluan}

Pendidikan adalah sesuatu yang universal dan berlangsung terus tak terputus dari generasi ke generasi dimanapun di dunia ini. Upaya memanusiakan manusia melalui pendidikan itu diselenggarakan sesuai dengan pandangan hidup dan latar sosial-kebudayaan setiap masyarakat tertentu. Oleh karena itu, meskipun pendidikan itu universal, namun terjadi perbedaan-perbedaan tertentu sesuai dengan pandangan hidup dan latar sosiokultural tersebut (Tirtarahhardja, 2010)

Pada awal abad ke-20, kebijakan penjajahan Belanda mengalami perubahan arah yang paling mendasar. Eksploitasi terhadap Indonesia, sebagai pembenaran utama atas kekuasaannya, mulai berkurang dan digantikan dengan pernyataanpernyataan keprihatinan atas kesejahteraan bangsa Indonesia. Kebijakan itu dinamai politik etis yang berpangkal pada gagasan kewajiban moral dan hutang budi ( een eeresschuld) pemerintah kolonial terhadap tanah jajahan. Pidato tahunan Ratu Wilhelmina dari takhta kerajaan pada September 1901 yang mengumandangkan bermulanya zaman baru dalam politik kolonial yang lazim disebut politik etis dengan trilogy kebijakan edukasi,irigasi dan emigrasi (Husain, 2015). Pada periode ini pendidikan mendapat perhatian khusus.

Kebijakan pada masa Hindia Belanda dalam bidang pendidikan untuk orangorang pribumi. Kurikulum ditentukan dan dikuasai oleh pemerintah yang menginginkan kurikulum yang sederhana mungkin sehingga lulusannya tidak mampu melakukan pekerjaan administrasi di kantor dan karena itu tidak akan meninggalkan desanya. Kurikulum yang digunakan di sekolah desa adalah (volkschool) seperti belajar menulis,menghitung dan membaca (Nasution, 2011). Pada masa Hindia Belanda di Enrekang telah ada Sekolah yang disebut Volkschool atau sekolah rakyat.
Lain halnya dengan pemerintah Hindia Belanda dimana pada masa itu ada semacam diskriminasi antar sekolah untuk bangsawan dan pribumi, Jenis sekolah sarana dan prasarana dibedakan termasuk lamanya pendidikan. Pada masa pendudukan Jepang diskriminasi dihapuskan dan lama pendidikan di seragamkan.

Dizaman kemerdekaan, sistem pendidikan Jepang di lanjutkan oleh pemerintah Republik Indonesia dengan alasan sistem pendidikan Jepang sangat cocok dengan Negara yang baru di proklamasikan dan membangun mental dan karakter bangsa dari ancaman Belanda dalam usahanya untuk menguasai kembali daerah jajahannya. Sistem pendidikan tersebut kemudian diterapkan di semua wilayah kedaulatan RI termasuk di Enrekang (Sari, 2014).

Pendidikan rendah adalah sekolah dasar yang sejak awal kemerdekaan di sebut Sekolah Rakyat (SR). Lama pendidikan yang semula tiga tahun menjadi enam tahun. Tujuan didirikannya Sekolah Rakyat (SR) ini adalah meningkatkan taraf pendidikan pada zaman sebelum kemerdekaan. Dan juga dapat menampung hasrat yang besar dari mereka yang hendak bersekolah. Mengingat kurikulum SR diatur sesuai dengan putusan menteri PK tanggal 19 November 1946 No. 1153/Bhg. A, yang menetapkan daftar pelajatran sekolah rakyat (SR) dimana lebih menekankan pelajaran bahasa dan berhitung.hal ini dapat dilihat bahwa dari 38 jam pelajaran dalam seminggu, delapan jam adalah untuk bahasa Indonesia, empat jam untuk bahasa daerah, dan tujuh jam berhitung (kelas IV,V,VI) (Rifa'i, 2014) .

Sekolah rakyat di Enrekang pada tahun 1950 masih dalam keadaan sangat terbelakang. Terutama gedung-gedung sekolah yang belum memuaskan keadaanya. Terdapat beberapa sekolah yang kekurangan gedung seperti pada SR 3 tahun I dan II di Enrekang. Hanya ada 2 gedung yang difungsikan dari kedua sekolah tersebut karena ke 3 gedung dari 
SR 3 Tahun I diduduki oleh tentara. Sehingga murid-murid tidak ada tempat untuk sekolah. Hanya gedung SR II yang digunakan untuk kelas 3 kedua SR tesebut. Sedangkan proses belajar mengajar untuk kelas 1 dan 2 dilakukan di bawah kolong rumah yang agak besar. Hal ini sangat menyusahkan pengajaran kedua sekolah ini. (RI Wilayah Ujung Pandang, 18901971). Berhubung dengan semakin banyaknya anak-anak yang berminat sekolah ditandai dengan jumlah murid telah meningkat maka pada tahun ajaran 1951 yaitu pada bulan juli Sekolah Rakyat 3 tahun di Maroangin dan Sekolah rakyat 4 tahun di Baroko diubah menjadi Sekolah Rakyat 6 Tahun (RI Wilayah Ujung Pandang, 1890-1971).

Pada tahun 1958 sekolah rakyat semakin meningkat. Ditandai dengan bertambahnya sekolah yang menjadi SR 6 tahun. Di daerah Enrekang pada tanggal 1 Desember 1957 terdapat 5 sekolah yang menjadi SR 6 Tahun yaitu SR Bisang, SR panette, SR Malawwe, SR Bamba dan SR tembang (RI Wilayah Ujung Pandang, 1890-1971). Olehnya itu Berdasarkan hal tersebut diatas maka penulis tertarik untuk mengkaji dan menyajikan dalam bentuk tulisan dengan judul "Sekolah rakyat di Enrekang (1950-1959)”.

\section{B. Metode Penelitian}

Dalam penyajian suatu penelitian yang benar dan dapat dipertanggungjawabkan, maka penelitian serta pengumpulan data yang akurat dan dapat dipercaya serta relevan untuk menjadi bahan analisis bagi pembahasan materi pokok penulisan.

Penelitian dan pengembangan data dilakukan melalui hasil yang tepat dan akurat jika menggunakan metode yang tepat pula. Data merupakan suatu hal yang sangat penting dan merupakan pendukung dalam suatu penulisan, walaupun hal itu tidak mudah untuk diperoleh begitu saja. Data tersebut diperoleh melalui suatu proses kegiatan dengan cara-cara atau prosedur ilmiah tertentu yang disebut metode penelitian.
Metode penelitian yang digunakan ialah kualitatif. Metode ini sering digunakan dalam ilmu sejarah dan ilmu sosial lainnya dengan tujuan untuk menemukan suatu hal yang unik dan mampu mengungkapkan peristiwa yang telah terjadi di masa lampau.

\section{Heuristik}

Tahap ini merupakan tahap awal dalam penelitian, yakni mencari dan mengumpulkan sumber-sumber atau data yang berhubungan dengan topik yang akan penulis teliti yaitu " Sekolah Rakyat di Enrekang (1950-1959). Dalam tahap pengumpulan data atau sumber ini banyak menyita waktu, biaya, tenaga, pikiran juga perasaan (Sjamsuddin, 2012)

Sumber sejarah primer adalah orangorang yang terlibat langsung dalam kejadian atau saksi kejadian,atau sumber dokumentasi yang berhubungan dengan kejadian tersebut. sedangkan sumber sejarah sekunder adalah pikiran dari orang yang bukan pengamat ( bukan saksi mata) juga berada antara peristiwa dan pemakai catatan (Darmadi, 2014).

Pengumpulan sumber untuk mengkaji penelitian ini adalah diantaranya mengumpulkan sumber primer berupa arsip yang diperoleh dengan mengunjungi Dinas perpustakaan dan Arsip Daerah Sulawesi Selatan. Arsip yang digunakan yaitu inventaris arsip statis pemerintah daerah tingkat II Enrekang (1890-1971) mengenai pendidikan: tentang laporan tournae ke wilayah pemilik sekolah Enrekang , No. Reg. 45. Masih menggunakan arsip yang sama tanggal 13 juli 1951 tentang perubahan kedudukan sekolah rakyat 6 tahun, No. Reg. 237. Arsip pemerintah Daerah Kota madya Pare-pare Volume I periode 1889-1981 mengenai pendidikan: surat tanggal 2 juni 1956 tentang daftar sekolah yang tertutup dan terbakar No. Reg 508. Selain arsip sumber primer juga berupa wawancara terhadap beberapa narasumber yang pernah menjadi murid dan guru di Sekolah Rakyat.

Sumber sekunder diperoleh dengan mengumpulkan buku dan skripsi terkait 
pendidikan sebagaimana disebutkan dalam kajian relevan. Buku dan skripsi tersebut diperoleh dengan mengunjungi Perpustakaan Wilayah Sulawesi Selatan, Perpustakaan Jurusan Pendidikan Sejarah FIS UNM, BPNB, perpustakaan pusat Universitas Negeri Makassar serta Perpustakaan pusat Universitas Hasanuddin.

\section{Kritik}

Tahap kedua adalah kritik sumber. Sumber-sumber yang telah dikumpulkan baik sumber tertulis maupun sumber lisan kemudian diverifikasi atau diuji melalui kritik baik yang bersifat intern maupun ekstern.

Kritik Intern dilakukan untuk menilai kelayakan sumber. Kelayakan sumber biasanya mengacu pada kemampuan sumber untuk mengungkap kebenaran suatu peristiwa. Kemampuan sumber meliputi kompetensi, kedekatan, atau kehadiran sumber dalam peristiwa sejarah.

Kritik ekstern dilakukan untuk mengetahui sejauh mana keabsahan dan autentitas sumber. Kritik terhadap autentitas sumber tersebut misalnya dengan melakukan pengecekan tanggal penerbitan dokumen, pengecekan bahan yang berupa kertas atau tinta apakah cocok dengan masa di mana bahan semacam itu biasa digunakan atau diproduksi. Memastikan suatu sumber apakah termasuk sumber lisan atau salinan. Apakah itu penulisan ulang atau hasil fotocopi (Madjid, 2014).

\section{Interpretasi}

Pada tahap ini dilakukan penafsiran terhadap data-data yang telah diseleksi. Data-data yang tadinya telah melalui tahap kritik intern dan tahap eksternal harus melalui tahap interpretasi untuk menafsirkan data-data yang telah diperoleh. Proses penafsiran juga harus meliputi seleksi fakta yakni memlih fakta yang relevan demi kepentingan penelitian. Selain itu harus meliputi periodisasi, yaitu penyusunan fakta sesuai dengan urutan periodik (urutan waktu terjadinya) (Darmadi, 2014)

\section{Historiografi}

Merupakan tahap terakhir dalam metode penelitian sejarah yang digunakan oleh penulis. Dalam tahap ini data-data yang tadinya telah ditafsirkan kemudian dirangkaikan menjadi sebuah tulisan untuk dapat mengungkapkan kisah sejarah yang diteliti secara kronologis yang menjadi objek kajiannya

Historiografi merupakan puncak dari penelitian yang dilakukan. Dalam metode ini penulis mencoba menangkap dan memahami realita sejarah dimana penulis tidak hanya terpaku pada jawaban dari "apa”, "kapan”, “dimana” dan “ bagaimana”. Suatu peristiwa itu terjadi tetapi melakukan suatu eksplanasi secara kritis tentang "bagaimana" dan "mengapa" atau penyebab peristiwa tersebut terjadi. Pada tahap ini fakta-fakta yang telah diperoleh dan diinterpretasikan selanjutnya akan dirangkaikan untuk mengungkapkan peristiwa sejarah yang menjadi permasalahan dalam karya ilmiah ini secara kronologis dan mengungkapkan maknanya.

\section{Tinjauan Penelitian}

Massenrempulu berasal dari kata Massere-Bulu ( bahasa Bugis), berarti daerah sekitar pegunungan. Istilah itu digunakan sejak masa kerajaan, hingga pembentukan pemerintah kabupaten tahun 1960. Ketika pembentukan pemerintahan kabupaten, wilayah-wilayah yang dulunya tergabung dalam persekutuan atau federasi Massenrempulu tersebar dalam beberapa kabupaten. Pitu Riase yang sebelumnya menjadi bagian dari persekutuan masuk dalam wilayah Kabupaten Sidenreng Rappang. Kerajaan-kerajaan Batulappa, Kassa dan kerajaan Letta masuk dalam wilayah pemerintahan Kabupaten Pinrang. Binuang yang pada awal pembentukan persekutuan juga merupakan bagian Massenrempulu yang dikenal dengan sebutan pitu Massenrempulu, sekarang masuk ke dalam wilayah pemerintahan propinsi Sulawesi Barat.

Wilayah Massenrempulu pada masa sekarang, meliputi sebagian wilayah pada 
Kabupaten Sidenreng Rappang dibagian selatan, Bagian Barat Kabupaten Pinrang, semua wilayah kabupaten Enrekang dan sebagian wilayah Kabupaten Polewali Mandar Provinsi Sulawesi Barat (Sitonda, 2012)

Secara geografis Kabupaten Enrekang terletak di antara 3'14'36',-3' 50'00 Lintang Selatan dan 119'40'53"' Bujur Timur. Secara umum penduduk yang mendiami Kabupaten Enrekang sekarang, dalam kajian orang barat berasal dari Bugis dan berkerabat dengan penduduk asli Massenrempulu dan Tana Toraja. Mengenai asal usul manusia pendukung daerah itu,perlu penelitian khusus, karena berkaitan dengan migrasi manusia pendukung yang mendiami daerah yang ada sekarang di Sulawesi Selatan.

Berdasarkan kondisi geografisnya wilayah massenrempulu, yang memanjang dari batas selatan Sidenreng Rappang hingga batas utara Tana Toraja, mengakibatkan penduduk yang mendiami daerah itu, mempunyai perbedaanperbedaan sosial budaya masyarakatnya. Perbedaan yang menonjol adalah perbedaan dialek bahasa yang digunakan sehari-hari. Daerah yang bahagian selatan yang berbatasan dengan Sidenreng Rappang, penduduknya menggunakan Bahasa Bugis sebagai bahasa-bahasa pergaulan sehari-hari. Namun berbeda dan agak kasar dibandingkan dengan bahasa Bugis Bone yang halus. Jenis bahasa seperti itu, digunakan oleh orang-orang Enrekang bagian selatan seperti di Maiwa dan sekitarnya. Bahasa itu sekarang digunakan pada dua daerah pemerintahan Kecamatan yaitu Kecamatan Maiwa dan Kecamatan Maiwa atas.

\section{Pembahasan}

\section{Kebijakan dan Sistem Pendidikan di Enrekang}

Pada tanggal 17 Agustus 1950, Indonesia resmi kembali menjadi Negara kesatuan
Repoblik Indonesia. Dengan kembalinya Negara kesatuan ini, maka terjadi pulalah penyusunan kembali kementriankementrian RIS. Kementrian pendidikan dan kebudayaan kini berpusat di Jakarta. Terdapat beberapa kebijakan mengenai sekolah rakyat tersebut yaitu:

a. Kebijakan sekolah rakyat tingkat pusat Pusat

Kebijakan-kebijakan yang akan dilaksanakan oleh pemerintah Indonesia yang dalam kaitannya berhubungan dengan murid-murid, yaitu: (Luwu, 1918-1970)

1) Tiap-tiap warga Negara RI mempunyai hak yang sama untuk diterima menjadi murid suatu sekolah, jika anak tersebut memiliki syarat yang telah ditetapkan oleh menteri pendidikan dan pengajaran sekolah tersebut.

2) Peraturan-peraturan yang memuat syarat-syarat tentang peneriman, penolakan dan pengeluaran muridmurid ditetapkan oleh menteri pendidikan pengajaran dan kebudayaan.

3) Murid-murid yang pandai/ pintar namun tidak mampu membayar biaya sekolah, dapat menerima sokongan (beasiswa) dari pemerintah.

4) Untuk macam sekolah dapat diadakan peraturan pemberian sokongan kepada murid-murid, dengan perjanjian bahwa murid-murid tersebut sesudah tamat belajar akan bekerja dalam jawatan pemerintah untuk waktu yang telah ditetapkan.

Sementara itu mengenai uang sekolah dan uang alat-alat pelajaran pemerintah juga mengambil kebijakan bahwa di sekolahsekolah Rendah dan sekolah luar biasa tidak di pungut biaya (uang) sekolah maupun uang alat-alat pelajaran dalam bentuk apapun itu (Luwu, 1918-1970). Setelah tahun 1950, pemerintah melaksanakan beberapa tindakan dalam upaya perbaikan pendidikan dan pengajaran, antara lain:

1) Pengajaran agama dimasukkan ke dalam rencana pelajaran dengan maksud semua anak dapat mengikuti pelajaran 
agama di sekolah dan disediakan kesempatan sebaik-baiknya.

2) Semua anak yang cakap tanpa terkecuali dari manapun asalnya diberi kesempatan memperoleh pendidikan setinggi-tingginya.

3) Dalam pendidikan diterapkan prinsip demokratis,maksudnya setiap anak yang cakap dapat memasuki semua jenis sekolah

4) Persiapan kewajiban belajar di jalankan sejak tahun 1950 .

5) Pendidikan dan kebudayaan diusahakan bersifat nasional (Kamar, 2005)

Dalam sekolah-sekolah negeri diadakan pelajaran agama, orang tua murid menetapkan apakah anaknya mengikuti pelajaran agama tersebut atau tidak. Hal ini karena mengingat bahwa sebagian murid bukan beragama islam. Guru-guru juga diharapkan agar dapat menghargai agama masing-masing muridnya.

a. Pedoman kepada Guru, orang tua, dan masyarakat

Pada tahun 1950 terdapat pedoman yang harus dilaksanakan oleh seluruh Guru,orang tua dan masyarakat di Indonesia yang dikeluarkan atau diedarkan oleh pemerintah pusat. Maksud pemerintah mengeluarkan pedoman tersebut yaitu yang memegang peranan penting dalam usaha pendidikan ini ialah orang tua,guru dan masyarakat

b. Inspeksi pusat Sekolah Rakyat

Dalam pengurusannya mengenai sekolahsekolah rakyat (SR), tugas utama adalah meliputi bidang-bidang tekhnis edukatif. Seperti usaha-usaha pembaharuan rencana pembaharuan rencana pelajaran SR yang lebih sesuai dengan Undang undang Dasar Negara, Ideologi Negara Pancasila.

Pada umumnya kegiatan inpeksi Pusat Sekolah Rakyat meliputi:

1) nyusun aparat inpeksi diseluruh Indonesia untuk menjalankan segala peraturan negara dalam lapangan pendidikan dan pengajaran di sekolah rakyat

2) Mengusahakan penampungan anak-anak yang telah cukup umur di Sekolah
Rakyat. Untuk ini diadakan pula kursus-kursus pengantar ke kewajiban belajar ( Kpkb) yang kini telah menjadi sekolah-sekolah rakyat.

3) Menjelang pembaharuan pendidikan dan pengajaran science dan mata pelajaran ekspresi. Sekalipun SR itu masih jauh dari sempurna, namun telah tercapai suatu tingkatan yang menunjukkan kemajuan yang sangat besar, yakni dalam:

a. Jumlah sekolah-sekolah, baik negeri maupun partikiler naik dari 15.000 buah pada tahun 1945 menjadi 31.000 pada tahun 1955 .

b. Jumlah murid bertambah dari 2.523.410 pada tahun 1945 dan 7.034.239 pada tahun 1955, bisa dikatakan 3 kali lipat jumlah tahun 1945 (Aman, 1980) Aparat dan kewajiban Inpeksi Sekolah Rakyat dapat dilihat sebagai berikut: Bertempat berkedudukan di Jakarta dan merupakan salah satu bagian dari Jawatan Pengajaran, menyelenggarakan pimpinan dan pengawasan atau pendidikan dan pengajaran tingkatan rendah. Pendidikan dan pengajaran tingkatan rendah ini meliputi segala macam Sekolah Rakyat dan kursuskursus tingkatan sekolah rakyat baik Negeri maupun partikiler.

4) Kebijakan sekolah di tingkat provinsi Sulawesi Selatan

Setelah daerah Sulawesi Selatan termasuk dalam RIS, maka pada tanggaltanggal awal Oktober 1950, Sekertaris Jenderal pendidikan,pengajaran dan kebudaaayan, Mr Hadi berkunjung ke Makassar. Kunjungan ini memberi manfaat bagi perkembangan pendidikan di daerah ini. sebelumnya rakyat ragu akan masa depan pendidikan anak-anaknya. Perasaan yang sama terdapat pada guru-guru, gelisah menanti-nantikan kesatuan dalam sistem pendidikan dan pengajaran, terutama dalam hal bentuk-bentuk sekolah rakyat. Pada masa NIT tindakan dari kementrian pengajaran kurang memperhatikan hal demikian. 
Tibanya Mr. Hadi di Makassar melegakan rakyat dan para guru sekolah. Pada bulan Nopember 1950 dibentuk kantor inspeksi Sekolah Rakyat daerah X, yang meliputi seluruh daerah-daerah yang tercakup dalam provinsi Sulawesi Selatan. Sekolah rakyat sebagai lembaga pendidikan dasar menjadi perhatian utama. Wilayah kerja Badan penyelenggara Sekolah Rakyat ialah daerah-daerah kabupaten yang telah diserahi penyelengaraan sekolah-sekolah rakyat. Bidang kerjanya yaitu penerimaan murid, tata usaha keuangan, administrasi, alat-alat perlengkapan, alat-alat pengajaran, kepegawaian dan pengadaan serta pemeliharaan gedung. Badan tersebut memegang peranan penting dalam hal pelaksanaan penyelengaraan pendidikan dengan baik dan teratur dalam pengadaan gedung dan pekarangan sekolah.

\section{Sistem Pendidikan Sekolah Rakyat Di Enrekang}

Setelah Indonesia merdeka fokus utama pendidikan nasional adalah mencerdaskan dan meningkatkan kualitas serta kemapuan bangsa. Tujuan Sebenarnya dari pendidikan zaman kemerdekaan adalah untuk mengisi tata kehidupan dan pembangunan. Mohammad Yamin ( 19531955) adalah menteri pendidikan, pengajaran dan kebudayaan, pada masa itu memberikan penerangan posisi pendidikan sebagai landasan pembangunan masyarakat Indonesia secara nasional, artinya pendidikan harus mengangkat tata nilai sosial yang menjadi tradisi, Bahasa, agama, ras dan sukunya yang beragama untuk menggantikan sistem pendidikan warisan kolonial. Secara garis besar, pendidikan nasional adalah bentuk reaksi atas sistem pendidikan yang bersifat deskriptif dan elitis. Oleh karenanya tujuan pendidikan nasional adalah membentuk masyarakat yang demokratis.

a. Pengertian Sekolah Rakyat

Pendidikan rendah adalah sekolah dasar yang sejak awal kemerdekaan disebut Sekolah Rakyat (SR). Lama pendidikan yang semula tiga tahun menjadi 6 tahun. Tujuan didirikannya Sekolah Rakyat (SR) ini adalah meningkatkan taraf pendidikan pada masa sebelum kemerdekaan. Dan juga dapat menampung hasrat yang besar dari mereka yang hendak bersekolah.

b. Tujuan Pendidikan Sekolah Rakyat

Maksud dari pendidikan dan pengajaran rendah (Sekolah Rakyat ) mengingat undang-undang No. 4 tahun 1950 adalah menuntut tumbuhnya rohani dan jasmani anak-anak di Indonesia, termasuk Enrekang,memberikan kesempatan kepada mereka guna mengembangkan bakat dan kesukaannya masing-masing, dan mem berikan dasar-dasar pengetahuan,kecakapan dan ketangkasan, baik lahir maupun batin

c. Guru Sekolah Rakyat

Pada tahun 1950 di Sulawesi Selatan telah terdapat sekitar 900 buah Sekolah Rakyat (SR). karena itu pemerintah berusaha meningkatkan mutu pendidikan,perlu melakukan tenaga pengajar.prioritas pertama ialah calon guru SR. karena lembaga pendidikan ini merupakan dasar untuk lanjut ke tingkat pendidikan yang lebih tinggi (Kebudayaan, 1982).

Sebagai realisasi pengadaan guru lewat K.P Kpkb (kursus-kursus pengajaran untuk kursus pengantar ke kewajiban belajar), maka pada tanggal 1 Desember 1950 di seluruh propinsi Sulawesi Selatan dibuka 17 buah. Tahun ajaran 1952/1953 di buka lagi 5 yaitu di Makassar,Takalar, Labakkang, Enrekang dan Sinjai.

d. Minat Murid

Dalam proses penerimaan siswa baru di Enrekang cukup unik yaitu murid yang masuk tidak di lihat dari umur tapi kemampuan siswa untuk memegang telinga, mengangkat tangan kanan keatas, kemudian di tekuk ke ubun-ubun kepala hingga ujung jari tangan kanan menyentuh telinga sebelah kiri. jika dapat menyentuh telinga kiri maka anak tersebut sudah dapat di terima dan jika tidak menyentuh telinga kiri maka anak tersebut belum bisa masuk sekolah meskipun umurnya sudah tujuh tahun (Madani, 2019) 
Terdapat juga syarat lain untuk masuk sekolah yaitu syarat dari orang tua. Syarat tersebut adalah anak sudah bisa menyebrang kali, kencang lari dan tahan lapar. Adanya syarat dari orang tua karena setiap saat bisa saja terjadi kekacauan. Olehnya itu pada saat terjadi kekacuan anak bisa menyelamatkan diri. (Sitonda, 2019)

e. Kondisi dan peralatan sekolah rakyat

Sekolah rakyat di Enrekang pada tahun 1950 masih dalam keadaan sangat terbelakang.terutama gedung-gedung sekolah yang belum memuaskan keadaanya. Terdapat beberapa sekolah yang kekurangan gedung seperti pada SR 3 tahun I dan II di Enrekang. Hanya ada 2 bilik yang difungsikan dari kedua sekolah tersebut karena ke 3 bilik dari SR 3 Tahun I diduduki oleh tentara. Sehingga muridmurid tidak ada tempat untuk sekolah. Hanya gedung SR II yang digunakan untuk kelas 3 kedua SR tesebut. Sedangkan proses belajar mengajar untuk kelas 1 dan 2 dilakukan di bawah kolong rumah yang agak besar. Hal ini sangat menyusahkan pengajaran kedua sekolah ini. Keadaan sekolah rakyat Sambungan di Kalosi mempunyai gedung sekolah atau bilik tambahan yang buruk kekurangan 3 bilik. Bilik tersebut beratapkan seng (Bilik tambahan alang-alang), lantai buruk, tiangtiang baik kecuali bilik tambahan dan dinding dari Bambu. Gedung tersebut tidak mencukupi untuk menampung siswa. Sarana sekolah Rakyat pada tahun 1950-an selain gedung sekolah yaitu bangku/ meja untuk belajar, buku atau papan batu dan papan tulis yang digunakan murid belajar sebagian bantuan dari pemerintah dan sebagian pun swadaya dari masyarakat setempat.

\section{f. Kurikulum}

Kurikulum yang digunakan pada sekolah rakyat di Indonesia termasuk Enrekang pada tahun 1950-1959 adalah kurikulum rencana pelajaran terurai 1952. Landasana Yuridis kurikulum 1952 tidak berbeda jauh dari kurikulum 1947.landasan idiilnya adalah pancasila yang tercantum dalam pembukaan UUD 1945, sedangkan landasan konstitusionalnya adalah UUD 1945. Landasan Operasional kurikulum 1952 adalah UU No. 4 Tahun 1950 (Agung, 2015).

Kurikulum pendidikan rendah ini ditujukan untuk menyiapkan anak memiliki dasar-dasar pengetahuan, kecakapan dan ketangkasan baik lahir maupun batin, serta mengembangkan bakat dan kesukaannya.

Pada tahun 1952, kementrian pendidikan pengajaran dan kebudayaan menerbitkan buku pedoman kurikulum SD yang diberi nama "rencana pelajaran terurai untuk Sekolah Rakyat III dan IV". Fungsinya untuk membimbing para guru dalam kegiatan mengajar di sekolah terhadap murid sekolah dasar. Organisasi kurikulum yang digunakan adalah separated curriculum, sedangkan mata pelajaran yang diuraikan dalam rencana pembelajaran meliputi: Bahasa Indonesia, Bahasa Daerah, Berhitung, Ilmu Alam, ilmu Hayat. Ilmu bumi, sejarah. Dalam prakteknya selain pelajaran tersebut diberikan juga pembelajaran lain seperti: menyanyi, menggambar, pekerjaan tangan dan olah raga (Wiryokusumo, 1988).

\section{Perkembangan Sekolah Rakyat di Enrekang}

Dalam pembahasan ini sudah dijelaskan pada bab dua bahwa pada tahun 1907 Volkschool didirikan secara merata di daerah-daerah termasuk Enrekang. Pada tahun 1926 didirikan sekolah Rakyat Di Enrekang bagian duri masing-masing di Redak, Baroko dan Curio. Tidak ada data yang menyebutkan bahwa kapan dan dimana tepatnya Volkschool pertama yang didirikan di Enrekang

Sekolah rakyat di Enrekang pada tahun 1950 an berjumlah 34 sekolah. yang terdiri dari sekolah rakyat 3 tahun, sekolah rakyat 4 tahun dan sekolah rakyat 6 tahun yang tersebar di berbagai distrik dan kampung-kampung.

Faktor kesulitan gedung-gedung dan alatalat kelengkapan sekolah, tidak menjadi penghambat bagi masyarakat menuntut ilmu, hal ini dibuktikan dengan 
bertambahnya jumlah murid di Sekolah Rakyat yang ada di Sulawesi Selatan termasuk Enrekang Sendiri. Pada tahun 1951 jumlah murid di beberapa sekolah meningkat sehingga sekolah-sekolah itu di ubah kedudukannya dari sekolah rakyat 3 tahun menjadi Sekolah rakyat 6 tahun.

Peralatan yang digunakan pada sekolah juga mengalami peningkatan seperti pada tahun 1952 masih menggunakan meja yang terbuat dari bambu, alat tulis yang digunakan adalah batu tulis dan papan batu. Sekitar tahun 1956 sudah meggunakan meja dari papan dan alat tulis sudah ada pensil, buku dan tinta. Namun buku pada saat itu belum sebagus buku yang sekarang. Warnanya masih buram dan masih sulit didapatkan.

Mengingat kondisi keamanan di Sulawesi Selatan yang belum stabil termasuk Enrekang, pada tahun 1956 terdapat beberapa sekolah rakyat yang terbakar dan tertutup (tidak digunakan lagi). Sekolah- sekolah yang terbakar disebabkan adanya kekacauan. Pada saat itu terjadi kekacauan yang menyebabkan banyak rumah penduduk dan sekolah yang di bakar. Seperti sekolah rakyat IV tahun di Sossok yang pada mulanya masih berjalan seperti biasanya namun setelah adanya pembakaran, sekolah tersebut di pindahkan ke cakke bersamaan dengan pindahnya penduduk di daerah tersebut. (Madani, 2019)

Sementara sekolah yang tertutup di sebabkan karena adanya pengungsian. Penduduk yang ada di hutan mengungsi ke kota karena sudah tidak sanggup tinggal di daerahnya akibat kekacauan. Yang dimaksud dengan sekolah yang tertutup adalah sekolah-sekolah yang tidak digunakan lagi untuk proses belajar mengajar seperti biasanya. Banyak terjadi pembakaran seperti rumah bahkan makanan. Hal ini menyebabkan banyak masyarakat yang mengungsi termasuk guruguru sekolah rakyat. Beberapa guru yang mengajar di Sekolah rakyat mengungsi secara diam-diam ke kota. Mereka berjalan kaki selama beberapa hari membawa keluarganya. Adanya pengungsian ini menyebabkan beberapa sekolah di tutup seperti pada tabel di atas (Rangan, 2019).

Meskipun pada tahun 1951 ada surat edaran bahwa semua sekolah rakyat yang hanya sampai kelas III di ubah menjadi sekolah rakyat VI tahun namun ada beberapa sekolah rakyat di Enrekang yang baru tahun 1958 di ubah kedudukannya menjadi SR VI tahun. Hal ini dikarenakan kebijakan tersebut dikembalikan ke daerah masing-masing apakah sekolah tersebut sudah layak menjadi SR VI tahun atau belum.

Sekolah-sekolah yang di maksud adalah sekolah yang jumlah muridnya telah meningkat sehingga sekolah terebut diubah kedudukannya menjadi sekolah rakyat VI tahun. Sekolah rakyat tersebut diantaranya SR Bisang. SR Panette, SR malawwe, SR Baba dan SR tembang.

Sampai tahun 1959-1960 beberapa sekolah Belum di gunakan (tertutup) dan baru kembali di buka pada saat keadaan sudah pulih. Sekolah-sekolah yang masih berjalan semakin menunjukkan perkembangannnya. Sekolah yang di maksud adalah sekolah yang berada di kota atau wilayah yang aman dari kekacauan seperti sekolah rakyat Kalosi dan sekolah Rakyat Enrekang yang pada saat namanya diubah menjadi Sekolah dasar menjadi Sekolah Dasar 1 Kalosi dan Sekolah Dasar 1 Enrekang.

\section{Partisipasi Pemerintah dan Masyarakat Enrekang}

Partisipasi pemerintah sangat penting dalam dunia pendidikan. Pemerintah menata pendidikan menuju otonomi daerah dengan cara menata propesionalisme guru, permasalahan profesionalisme guru,perbaikan fasilitas pendidikan serta membangun siswa yang berkualitas

Keberhasilan pendidikan sekolah juga tidak hanya ditentukan dari partisipasi pemerintah saja namun juga ditentukan oleh tingkat partisipasi masyarakat. Tidak adanya kesadaran masyarakat untuk 
memperoleh pendidikan maka semua yang dilakukan pemerintah tidak ada gunanya.

Pemerintah memperbaharui sistem pendidikan Indonesia sejak Proklamasi 17 Agustus 1945, sehingga pada tahun 1946 Menteri PP dan K ( Mr. Soewandi) membentuk panitia penyelidik pendidikan yang diketuai oleh Ki Hajar dewantara Yang tugasnya dasar-dasar da nisi, susunan dan seluruh usaha pendidikan. Hasilnya berkenaan dengan kurikulum menetapkan bahwa setiap rencana pelajaran pada setiap jenjang pendidikan sekolah hendaknya meningkatkan pendidikan jasmani dan meningkatkan pendidikan watak (Kamar, 2005).

Partisipasi pemerintah dalam pendidikan tepatnya sekolah rakyat mengenai perbaikan gedung-ge dung sekolah. kita ketahui bahwa sekitar tahun 1950-an di Indonesia masih dalam tahap pembangunan termasuk daerah Enrekang. Seiring pertumbuhan penduduk yang semakin pesat, maka perlu pula dengan peningkatan sarana dan prasarana. Ada pula usaha pemerintah Kabupaten Enrekang bersama masyarakat untuk mengatasi semakin banyak anak-anak usia sekolah maka segera mendirikan gedunggedung baru, menyewa rumah-rumah rakyat.

Untuk menunjang proses belajar mengajar yang lebih baik perlunya perlengkapan alat tulis menulis, seperti buku tulis ( pada saat itu yang digunakan papan batu yang berbentuk segi empat), pensil, papan tulis dan kapur serta tinta, menurut Ibu Hanafia pemerintah pada saat itu hanya memberikan bantuan ssekali saja selama bersekolah di SR, selebihnya semua tersebut rusak atau habis para murid membeli atau membuat sendiri, terkecuali kapur yang digunakan oleh guru.

Pemerintah membantu menyediakan rumah bagi guru-guru yang melakukan pengungsian dan memberikan beras Pemerintah juga hanya menyediakan satu buku cetak buku bahasa yang digunakan guru-guru mengajar dan untuk pelatihan membaca murid-murid. Pada saat itu juga pemerintah tidak pernah mengintimidasi para guru.

Masyarakat Enrekang sangat berpartisipasi dalam pendidikan sekolah rakyat pada tahun 1950-1959 dapat di lihat dengan jumlah murid yang semakin bertambah dan juga jika gedung-gedung ,sekolah rusak masyarakat langsung andil dalam memperbaiki gedung, jika papan tulis dan bangku rusak masyarakat atau orang tua muridlah yang memperbaiki atau membuat yang baru. Apalagi di daerah yang rawan akan kekacauan, ketika sekolah rusak atau terbakar masyarakat kemudian memperbaiki atau mendirikan sekolah yang baru pada saat kondisi sudah kondusif (Sitonda, 2019)

Saat gedung sekolah rusak atau dalam tahap perbaikan beberapa masyarakat bersedia kolong rumahnya di gunakan untuk proses belajar mengajar. Begitu juga ketika sekolah yang ada di Sossok di pindahkan ke Cakke karena gedungnya tidak cukup untuk menampung murid maka digunakan kolom rumah warga untuk kelas IV,V dan VI (Deri, 2019).

\section{E. Kesimpulan}

Setelah lima tahun merdeka pemerintah menata Indonesia termasuk Enrekang terutama dalam bidang pendidikan. Pada awalnya mata pelajaran belajar menulis,membaca dan berhitung, akhirnya bertambah seperti belajar sejarah, ilmu bumi, bahasa Indonesia, menggambar, seni suara, pendidikan Jasmani dan pendidikan rohani . Dalam perkembangan Sekolah Rakyat Di Enrekang tahun 19591960 masih dalam tahap pembangunan dan mulai ada perubahan dibanding dengan awal kemerdekaan. Sekolah rakyat yang pada awal kemerdekaan hanya sampai 3- 4 tahun, selang lima tahun kemerdekaan pemerintah berupaya mengubah menjadi 
sekolah rakyat 6 tahun termasuk sekolah rakyat di Kalosi yang kemudian dikenal dengan naman SD 1 Kalosi. Namun pada tahun 1956 ada beberapa sekolah yang terbakar dan tertutup akibat kekacauan.

Kesadaran masyarakat Enrekang tehadap pendidikan sangat penting dalam perkembangan sekolah rakyat. Dalam hasil wawancara yang penulis lakukan yaitu saat gedung sekolah mengalami kerusakan orang tua murid dan masyarakat setempat bergotong royong untuk memperbaikinya, tidak hanya gedung saja mereka juga memperbaiki fasilitas lainnya. Kesadaran masyarakat lainnya yaitu jumlah murid semakin bertambah tiap tahunnya. Masyarakat Enrekang sangat menghargai seorang guru. Terkadang mereka memanggil seorang guru dengan sebutan tuan guru. Saat guru menghardik anak-anak mereka, mereka tidak pernah marah malahan sebagian orangtua jika anaknya tersebut mengadu mereka memukul atau menghardik anaknya kembali. Dalam keberhasilan pendidikan tidak hanya partisipasi masyarakat saja yang diperlukan namun pemerintah pun harus turut andil dalam kemajuan pendidikan. Pada tahun 1950an pemerintah hanya dapat memberikan bantuan seadanya saja hal ini karena Indonesia baru saja merdeka dan dalam tahap pembangunan. Untuk urasan sekolah pemerintah tidak ikut campur mengenai kedisplinan guru terhadap muridmurid sekolah kecuali pembangunan gedung sekolah, gaji guru dan lain-lainnya.

\section{F. Daftar Pustaka}

Agung, L., 2015. Sejarah Kurikulum. Yogyakarta: Ombak.

Aman, S., 1980. Perkembangan Organisasi Pengurusan Sekolah-sekolah di Indonesia. Jakarta: Kurnia Esa.

Darmadi, H., 2014. Metode Penelitian Pendidikan dan Sosial. Bandung: Alfabeta.
Darmadi, H., 2014. Metode Penelitian Pendidikan dan Sosial. Bandung: Alfabeta.

Deri, A., 2019. [Interview] (12 Juni 2019).

Husain, S. B., 2015. Sejarah Sekolah Makassar. Makassar: Ininnawa.

Kamar, I. D., 2005. Potret Pendidikan Indonesia Dalam Deretan Masa. Makassar: Yabudo Press.

Kamar, I. D., 2005. Potret Pendidikan Indonesia Dalam Deretan Masa. Makassar: Yabudo Press.

Kebudayaan, D. P. d., 1982. Sejarah Pendidikan Daerah Sulawesi Selatang. Ujung Pandang: s.n.

Luwu, I. A., 1918-1970. Tentang Undangundang Noor 4 Tahun 1950 Mengenai Dasar Pendidikan dan Pengajaran di Sekolah. Luwu: s.n.

Madani, 2019. [Interview] (8 Juni 2019).

Madjid, M. D., 2014. Ilmu Sejarah Sebuah Pengantar. Jakarta: Prenada Media Group.

N., 2011. Sejarah Pendidikan Indonesia. Jakarta: Bumi Aksara.

Rangan, 2019. [Interview] (10 Mei 2019).

RI Wilayah Ujung Pandang, A. N., 18901971. Arsip Statis Pemerintah Daerah Tingkat II Enrekang 18901971. Ujung Pandang: s.n.

Rifa'i, M., 2014. Sejarah Pendidikan Nasional. Yogyakarta: Ar-ruzz Media.

Sari, P., 2014. Sejarah Pendidikan di Majene 1942-1960. Makassar: Universitas Hasanuddin.

Sitonda, 2019. [Interview] (14 Mei 2019).

Sitonda, M. N., 2012. Sejarah Massenrempulu Jilid I. Makassar: Yayasan Pendidikan Mohammad Natsir.

Sjamsuddin, H., 2012. Metodologi Sejarah. Yogyakarta: Ombak.

Tirtarahhardja, U., 2010. Pengantar Pendidikan. Makassar: Badan Penerbit UNM.

Wiryokusumo, I., 1988. Dasar-dasar Pengembangan Kurikulum. Jakarta: Bima Aksara. 